\title{
Revisiting proteus: Do Minor Changes in Lectin Structure Matter in Biological Activity? Lessons from and Potential Biotechnological Uses of the Diocleinae Subtribe Lectins
}

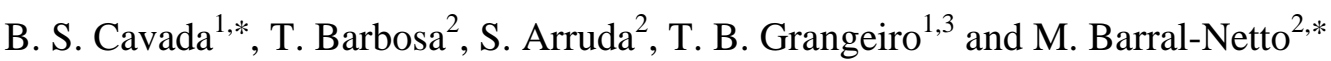

${ }^{1}$ BioMol - Lab, Departamento de Bioquímica e Biologia Molecular, Universidade Federal do Ceará; CP 6033; CEP 60.451-970 Fortaleza, Ceará, Brasil; ${ }^{2}$ LIMI - Laboratório de Imunoregulação e Microbiologia, CPqGM - FIOCRUZ; CEP 40295-001 Salvador - Bahia - Brasil; ${ }^{3}$ Laboratório de Citogenética e Genética Molecular, Departamento de Biologia, Universidade Federal do Ceará; CP 6033; CEP 60.451-970 Fortaleza, Ceará, Brasil.

\begin{abstract}
Significant differences in function have been observed among lectins structurally similar to concanavalin A, but their high homology with this widely used lectin has kept them in obscurity. The observation of large differences in the potency of many of these Diocleinae lectins as stimulators of Interferon- $\gamma$ production by human peripheral blood mononuclear cells has lead to a major effort to unravel their chemical structure and biological activity. Modeling studies of some of these lectins reveal conformational changes in side chains of some residues involved in the carbohydrate-binding site, with possible effects on the ability of these proteins to recognize specific carbohydrate structures. Additionally, all them constitute in fact a mixture of isolectins, which in different proportions could lead to diverse effects. The present review of the biological actions of Diocleinae lectins includes several in vitro and in vivo immunological findings, as well as their effects on insect growth and reproduction. In these systems Diocleinae lectins proved to be quite diverse in their potency. Such diversity in the biological activity of highly related proteins recalls the origin of the name protein: like Proteus, the capability of assuming various forms is the essential feature of this class of molecules.
\end{abstract}

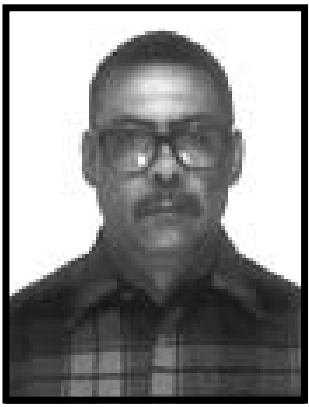

\section{INTRODUCTION}

Lectins are a structurally heterogeneous group of carbohydrate-binding proteins of nonimmune origin comprising distinct families of evolutionarily related proteins [1]. Sugar recognition mechanisms have evolved independently in diverse protein frameworks, and lectins are ubiquitous in animals, plants and microorganisms. Bacterial, viral, and animal lectins serve to mediate a wide variety of biological recognition events, such as cell comunication, host defense, fertilization, development, parasitic infection,

*Address correspondence to this author at the Centro de Pesquisas Gonçalo Moniz. Rua Waldemar Falcão, 121 - Brotas; CEP 40.295-001, Salvador, Bahia, Brasil; Tel: +55-71-356.4320 ext. 249; Fax: +55-71-356.2593; Email: mbarral@cpqgm.fiocruz.br and BioMol-Lab. Universidade Federal do Ceará. CEP 60.451-970, Fortaleza-Ce, Brasil; Tel: +55-85-288.9818; Fax:+55-85-288.9818; E-mail: bscavada@ufc.br tumour metastasis, inflammation, etc., by deciphering the glycocodes encoded in the structure of glycans attached to soluble and integral cell membrane glycoconjugates [2]. In contrast, and despite their abundance in many plants, plant lectins are enigmatic in that their true physiological functions are not clearly defined. Several experimental evidences support the hypotheses that plant lectins are defense proteins against herbivorous animals [3-5] and play a role in the symbiosis between nitrogen-fixing bacteria (Rhizobium spp.) and legume root hairs [6].

Besides their physiological roles, lectins are attracting increasing interest in biotechnology owing to their ability to bind carbohydrates with considerable specificity. In addition, lectins are excellent models for studying proteincarbohydrate interactions at the atomic level [7]. 
The most thoroughly investigated lectins are those from plants, in particular from the family Leguminosae. This family includes the plant species which the layperson refers to as beans, viz. Phaseolus spp., Vigna spp. and Glycine max. Legume lectins are a large group of structurally similar proteins with distinct carbohydrate specificities. Concanavalin A (ConA), from the seeds of Canavalia ensiformis (family Leguminosae, tribe Phaseoleae, subtribe Diocleinae), was the first lectin to be isolated [8], sequenced [9-10] and to have its three-dimensional structure determined by x-ray crystallography [11-12]. The many biochemical, biophysical, and structural studies carried out on ConA make this protein the best characterized plant lectin so far.

Uses of lectin are legion, and ConA has been widely evaluated in different systems. The isolation, purification and extensive characterization of ConA has resulted in less attention being paid to closely related lectins, especially those from species of the same subtribe Diocleinae [1320]. However, several lines of evidence reviewed in this paper demonstrate that these molecules present important variations in some biological activities, in spite of their high homology.

\section{CHEMICAL, PHYSICO-CHEMICAL AND STRUCTURAL PROPERTIES OF DIOC- LEINAE LECTINS}

Subtribe Diocleinae (Leguminosae) comprises 13 genera mostly from the New World [21], and lectins have been isolated from plants belonging to three of those genera, i.e. Canavalia, Cratylia and Dioclea. ConA was the first Diocleinae lectin to be isolated [8] and was the first lectin to have its primary structure determined [9-10] and to have its three-dimensional structure resolved by $\mathrm{x}$-ray crystallography $[11-12,22]$. ConA is a Dglucose/D-mannose specific lectin and its monomer contains 237 amino acid residues most of them arranged in two large anti-parallel $\beta$ sheets. This jelly-roll motif comprises a nearly flat six-stranded back $\beta$-sheet, a curved sevenmembered front $\beta$-sheet, a short five-membered top $\beta$-sheet, which has an important role in holding the two larger sheets together, and a number of loops interconnecting the sheets, as well as the strands that they contain. This is the legume lectin fold, which was first observed in ConA, and is the most widely observed fold in lectins [23]. ConA has a multimeric structure which displays $\mathrm{pH}-$ dependent dimer-tetramer interconversion. The carbohydrate-binding site of ConA is a shallow depression on the monomer surface and is made up of four loops at the top-front of the subunit. It is located close to the metal ions, i.e., $12 \AA$ from the $\mathrm{Mn}^{2+}$ binding site and $7 \AA$ from the $\mathrm{Ca}^{2+}$ binding site. Although the metal ions do not interact directly with the carbohydrate, they help to place the amino acid residues of the saccharide-binding site in the right position [12]. Since ConA was first isolated several lectins with similar physical properties have been purified and partially characterized from other Diocleinae species. The lectins are from Canavalia brasiliensis, $\mathrm{ConBr}$ [13], C. bonariensis, CABO [19], Cratylia floribunda, CFL [15], Dioclea grandiflora, DGL [14], D. guianensis, DGuiL [16], D. rostrata, DRL [17], D. violacea, DVioL [20], and D. virgata, DVirL [18]. All Diocleinae lectins studied so far have many chemical, physico-chemical and structural properties in common (Table 1). Therefore, this group of close related proteins have been named Diocleinae lectins. All of them are multimeric structures made up of identical monomers of $25.5 \mathrm{kDa}$, and they characteristically exhibit $\mathrm{pH}$-dependent dimer-tetramer equilibrium. They are metalloproteins requiring divalent ions $\left(\mathrm{Ca}^{2+}\right.$ and $\left.\mathrm{Mn}^{2+}\right)$ to exhibit full biological activity [13-20]. Each subunit also contains metal bindingsites for $\mathrm{Ca}^{2+}$ and $\mathrm{Mn}^{2+}$ ions and a hydrophobic cavity which binds hydrophobic ligands such as phytohormones [24]. All of these lectins share primary carbohydrate recognition specificity for D-mannose and D-glucose [25]. The x-ray crystal structures of ConBr [26], DGL [27] and DguiL [28] are similar to ConA. Electron paramagnetic resonance (EPR) and electron spin-echo envelope modulation (ESEEM) spectroscopy studies demonstrated that all Diocleinae lectins contain $\mathrm{Mn}^{2+}$ and also indicated the coordination of one histidine and two water molecules to $\mathrm{Mn}^{2+}$ [29]. In addition, the environment of the histidine is believed to be similar in all the lectins studied [29]. Therefore, Diocleinae lectins have extensive 
Table 1. Chemical and Physico-Chemical Properties of Diocleinae Lectins

\begin{tabular}{|c|c|c|c|c|c|c|c|}
\hline Lectin & Isolation & $\begin{array}{c}\text { Sugar } \\
\text { Specificity }\end{array}$ & $\begin{array}{l}\text { Erythrocyte } \\
\text { Specificity* }\end{array}$ & Mr kD & pI & $\begin{array}{c}\text { Metal } \\
\text { dependence }\end{array}$ & $\begin{array}{l}\text { Primary } \\
\text { Sequence }\end{array}$ \\
\hline Con $\mathrm{A}^{1}$ & Sephadex & Glu/Man & $\mathrm{R}>\mathrm{H}$ & $25 / 50 / 100^{* *}$ & $>8$ & Yes & Yes \\
\hline Con $\mathrm{Br}^{2}$ & Sephadex & Glu/Man & $\mathrm{R}>\mathrm{H}$ & $25 / 50 / 100$ & $>8$ & Yes & Yes \\
\hline Con $\mathrm{M}^{3}$ & Sephadex & Glu/Man & $\mathrm{R}>\mathrm{H}$ & $25 / 50 / 100$ & nd & Yes & Yes \\
\hline Con $\mathrm{G}^{4}$ & Sephadex & Glu/Man & $\mathrm{R}>\mathrm{H}$ & $25 / 50 / 100$ & nd & Yes & Yes \\
\hline $\mathrm{CABO}^{5}$ & Sephadex & Glu/Man & $\mathrm{R}>\mathrm{H}$ & $25 / 50 / 100$ & nd & Yes & No \\
\hline $\mathrm{DGL}^{6}$ & Sephadex & Glu/Man & $\mathrm{R}>\mathrm{H}$ & $25 / 50 / 100$ & $>8$ & Yes & Yes \\
\hline $\mathrm{DVL}^{7}$ & Sephadex & Glu/Man & $\mathrm{R}>\mathrm{H}$ & $25 / 50 / 100$ & nd & Yes & No \\
\hline $\mathrm{DRL}^{8}$ & Sephadex & Glu/Man & $\mathrm{R}>\mathrm{H}$ & $25 / 50 / 100$ & nd & Yes & No \\
\hline DvirL $^{9}$ & Sephadex & Glu/Man & $\mathrm{R}>\mathrm{H}$ & $25 / 50 / 100$ & nd & Yes & No \\
\hline $\operatorname{DguiL}^{10}$ & Sephadex & Glu/Man & $\mathrm{R}>\mathrm{H}$ & $25 / 50 / 100$ & nd & Yes & No \\
\hline $\mathrm{CFL}^{11}$ & Sephadex & Glu/Man & $\mathrm{R}>\mathrm{H}$ & $25 / 50 / 100$ & nd & Yes & No \\
\hline
\end{tabular}

${ }^{*} \mathrm{R}$, rabbit erytrocytes; $\mathrm{H}$, human erythrocytes. ${ }^{* *}$ monomer-, dimer- or tetramer-lectin, depending on $\mathrm{pH} ;$ nd = not done. ${ }^{1}$ Canavalia ensiformis lectin; ${ }^{2} \mathrm{C}$. brasiliensis lectin; ${ }^{3} \mathrm{C}$. maritima lectin; ${ }^{4}$ C. gladiata lectin; ${ }^{5} \mathrm{C}$. bonariensis lectin; ${ }^{6}$ Dioclea grandiflora lectin; ${ }^{7}$ D. violacea lectin; ${ }^{8}$ D. rostrata lectin; ${ }^{9}$ D. virgata lectin; ${ }^{10}$ D. guianensis lectin; ${ }^{11}$ Cratylia floribunda lectin.

structural homology with highly conserved functional binding sites.

However, despite the phylogenetic proximity and apparently highly conserved structures of the above Diocleinae lectins, they possess different biological activities such as histamine release from rat peritoneal mast cells [30], lymphocyte proliferation and interferon- $\gamma$ production [31], peritoneal macrophage stimulation and inflammatory reaction [32] as well as induction of paw edema and peritoneal cell immigration in rats [33].

One basis for different biological activity is variability in primary structure. A comparison of the primary structures of all Diocleinae lectins sequenced to date shows a high degree of homology (Fig. 1). The amino acid residues that in ConA are involved in the carbohydrate-binding site (Tyr12, Asn14, Leu99, Tyr100, Asp208 and Arg228), metal-binding site (Glu8, Asp10, Tyr12, Asn14, Asp19, His24, Val32, Ser34, Asp208 and Arg228) and hydrophobic cavity (Tyr54, Leu81,
Leu85, Val89, Val91, Phe111, Ser113, Val179, Ile181, Phe191, Phe212 and Ile214) are completely conserved in the primary structures of other Diocleinae lectins. As expected from this high primary structural homology, Diocleinae lectins have the same nominal monosaccharide specificity for D-mannose and D-glucose residues, but much higher affinities for the branched chain trimannoside, 3,6-di-O-( $\alpha$-D-mannopyranosyl)-Dmannose [34], which is found in the core region of all asparagine-linked (N-linked) carbohydrates. Furthermore, the lectins essentially recognize the same set of binding epitopes on the structure of the trimannoside [35]. However, it has been shown by hemagglutination inhibition, isothermal microcalorimetry (ITC) and surface plasmon resonance studies that they differ in their fine carbohydrate binding specificities, i.e. they have differential binding specificities for complex type carbohydrates [34-38]. Therefore, the differences in the intensity of biological activities induced by Diocleinae lectins are probably due, at least in part, to differences in their fine carbohydrate 
binding specificities. Indeed, the importance of determining the fine binding specificity of these lectins to explain their divergent biological activities led to the observation that the relative affinities of the lectins from $C$. brasiliensis (ConBr), C. bonariensis (CABO), C. floribunda (CFL), D. rostrata (DRL), D. virgata (DVirL), D. violacea (DVioL) and D. guianensis (DGuiL) for a naturally occurring biantenary complex carbohydrate with terminal GlcNAc residues $\left(\mathrm{GlcNAc}_{2} \mathrm{Man}_{5}\right)$ correlated with their relative histamine release activities in rat peritoneal mast cells $[30,34]$. One can speculate that the ability of Diocleinae lectins to produce different in vivo biological responses may be due to the relative affinities for their receptor (s) on the cells.

The x-ray crystal structures of ConA [39] and DGL [27] in complex with the core trimannoside show conserved contact residues for both proteins. The x-ray crystal structures of ConBr and DGuiL in complex with the core trimannoside are not yet determined. However, the multiple alignment of their primary structures with those of ConA and DGL show that ConBr and DGuiL also have these same contact residues (Fig. 1). The threedimensional structure of CFL is not yet determined. However, its complete primary sequence [40] show the conservation of these contact residues. In addition, although the complete primary sequences of DRL, DVirL and DVioL are not known, their N-terminal sequences are highly homologous with those above [41], and residues 12-16 that directly bind to the core trimannoside are conserved. Therefore, it is difficulty to explain the differences in the biological activities of these lectins, which are at least in part dependent on their relative affinities for complex carbohydrates, in terms of their structural differences.

It has been suggested that amino acid substitutions away from the carbohydrate binding site of Diocleinae lectins may be responsible for such differences in sugar binding affinities and biological activities. For instance, the x-ray crystal structure of ConBr shows only two amino acid changes relative to ConA [26, 42]. Gly-58 and Gly-70 in ConBr are replaced by Asp and Ala, respectively, in ConA. Neither of these residues are near the carbohydrate binding sites in both lectins, and only small changes in the quaternary structures of the two lectins were observed. However, these two amino acid replacements result in significant changes in some thermodynamic parameters of their binding to the core trimannoside. These results indicate that noncontact residues in Diocleinae lectins, even those distant from the carbohydrate-binding sites, modulate their thermodynamic binding parameters [34-35].

A second basis for different activity is the quaternary structure of a protein. In the case of ConBr, the lectin from Canavalia brasiliensis, important differences in the quaternary structure have been found in relation to ConA [26, 42] that may constitute the structural basis for explaining their distinct biological activities. The most relevant aspects of the quaternary structure of Diocleinae lectins are the subunit multivalency [41] and the relative orientation of the carbohydrate-binding sites [26].

Binding of multivalent lectins to cells results in the cross-linking of cell surface receptors which, in turn, is associated with a variety of biological signal transduction processes including mitogenesis [43]. All Diocleinae lectins characteristically display $\mathrm{pH}$-dependent dimer-tetramer interconversion (Table 1) [41]. Because each monomer has one sugar-binding site, dimers are divalent and tetramers are tetravalent. However, only the tetravalent form is able to cause the crosslinking of receptors on the cell membrane. Therefore, the range of different proportions between divalent and tetravalent forms observed for Diocleinae lectins may contribute to confer different potencies. For instance, ConBr shows an oligomerization behavior different from that reported for ConA. While ConA is a homogeneous tetramer at $\mathrm{pH}$ above 7 , ConBr displays a mixture of dimers $(31 \%)$ and tetramers $(69 \%)$ even at $\mathrm{pH}$ $8.5[26,42]$.

Recently, it has been suggested that these distinct $\mathrm{pH}$-dependent dimer-tetramer equilibria showed by Diocleinae lectins are due to mutations 


\begin{tabular}{|c|c|c|}
\hline & 1 & 45 \\
\hline ConA & ADTIVAVELDTYPNTDIGDPSYPHIGIDIKSVRSKKTAKWNMQNG & \\
\hline ConBr & ADTIVAVELDTYPNTDIGDPSYPHIGIDIKSVRSKKTAKWNMQNG & \\
\hline DGL & ADTIVAVELDSYPNTDIGDPNYPHIGIDIKS IRSKSTARWNMQTG & \\
\hline DguiL & ADTIVAVELDSYPNTDIGDPSYPHIGIDIKSIRSKSTARWNMQTG & \\
\hline \multirow[t]{2}{*}{ CFL } & 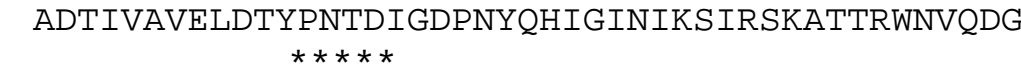 & \\
\hline & 46 & 90 \\
\hline ConA & KVGTAHI IYNSVDKRLSAVVSYPNADSATVSYDVDLDNVLPEWVR & \\
\hline ConBr & KVGTAHIIYNSVGKRLSAVVSYPNGDSATVSYDVDLDNVLPEWVR & \\
\hline DGL & KVGTVHISYNSVAKRLSAVVSYSGSSSTTVSYDVDLNNVLPEWVR & \\
\hline DguiL & KVGTAHISYNSVAKRLSAVVSYTGSSSTTVSYDVDLNNVLPEWVR & \\
\hline \multirow[t]{2}{*}{ CFL } & KVGTAHISYNSVAKRLSAIVSYPGGSSATVSYDVDLNNILPEWVR & \\
\hline & 91 & 135 \\
\hline ConA & VGLSASTGLYKETNTILSWSFTSKLKSNSTHETNALHFMFNQFSK & \\
\hline ConBr & VGLSASTGLYKETNTILSWSFTSKLKSNSTHETNALHFMFNQFSK & \\
\hline DGL & VGLSATTGLYKETNTILSWSFTSKLKTNS IADANSLHFSFNQFSQ & \\
\hline DguiL & VGLSATTGLYKETNTILSWSFTSKLKTNS IADANSLHFSFNQFSQ & \\
\hline \multirow[t]{2}{*}{ CFL } & $\begin{array}{c}\text { VGLSASTGLYKETNTILSWSFTSKLKTNSTADAQSLHFTFNQFSQ } \\
\star \star\end{array}$ & \\
\hline & 136 & 180 \\
\hline ConA & DQKDLILQGDATTGTDGNLELTRVSSNGSPQGSSVGRALFYAPVH & \\
\hline ConBr & DQKDLILQGDATTGTEGNLRLTRVSSNGSPQGSSVGRALFYAPVH & \\
\hline DGL & NPKDLILQGDAFTDSDGNLELTKVSSSGDPQGNSVGRALFYAPVH & \\
\hline DguiL & NPKDLILQSDATTDSDGNLELTKVSSSGDPQGSSVGRALFYAPVH & \\
\hline \multirow[t]{2}{*}{ CFL } & NPKDLILQGDASTDSDGNLQLTRVS-NGSPQSNSVGRALYYAPVH & \\
\hline & 181 & 225 \\
\hline ConA & IWESSAVVASFEATFTFLIKSPDSHPADGIAFF ISNIDSSIPSGS & \\
\hline ConBr & IWESSAVVASFEATFTFLIKSPDSHPADGIAFFISNIDSSIPSGS & \\
\hline DGL & IWESSAVVASFDATFIFLIKSPDHEPADGITFFIANTDTSIPSGS & \\
\hline DguiL & IWEKSAVVAGFDATFTFLIKSPDRDPADGITFFIANTDTSIPSGS & \\
\hline \multirow[t]{2}{*}{ CFL } & $\begin{array}{c}\text { VWDKSAVVASFDATFTFLIKSTDSDIADGIAWF IANTDSSIPHGS } \\
\star\end{array}$ & \\
\hline & $226 \quad 237$ & \\
\hline ConA & TGRLLGLFPDAN & \\
\hline ConBr & TGRLLGLFPDAN & \\
\hline DGL & GGRLLGLFPDAN & \\
\hline DguiL & GGRLLGLFPDAN & \\
\hline CFL & $\begin{array}{l}\text { GGRLLGLFPDAN } \\
\star\end{array}$ & \\
\hline
\end{tabular}

Fig. (1). Multiple alignment of the amino acid sequences of ConA (9-10, 39), ConBr (42), DGL (27), DguiL (41) and CFL (40). The asterisks indicate conserved contact residues (12-16, 99, 100, 208 and 228) of the lectins with the core trimannoside of asparagine-linked carbohydrates.

affecting key amino acid residues along their primary structures [28]. The comparison of the primary and quaternary crystal structures of DguiL and DGL indicate that substitution of His131 for Asn in the former drastically reduce interdimer contacts along with disordering of the loop comprising residues 117-123 which, in its ordered conformation, stabilises the $\mathrm{pH}$-independent tetrameric association of DGL. Hence, replacement of His for Asn at position 131 of DguiL yields a possible explanation for the existence in this lectin, but not in DGL, of $\mathrm{pH}$-dependent dimer-tetramer equilibrium [28, 41]. 
In addition, the crystal structure of $\mathrm{ConBr}$ solved at $3.0 \AA$ resolution shows a more open quaternary structure for ConBr than for ConA [26] which results in changes in the relative orientation of the carbohydrate-binding sites of these two highly homologous lectins. The determination of the complete amino acid sequence of $\mathrm{ConBr}$ [42] showed that this change in the relative orientation of the carbohydrate-binding sites between $\mathrm{ConBr}$ and ConA may be explained by a single amino acid substitution in the polypeptide chain that makes up the ConBr monomer. The occurrence of glycine at position 58 in $\mathrm{ConBr}$ does not allow formation of a hydrogen bond which in the ConA tetramer exists between aspartic acid 58 of subunit $\mathrm{A}$ and serine 62 of subunit $\mathrm{C}$. The consequence is that the $\alpha$ carbons of the corresponding residues in ConBr are $1.5 \AA$ closer than those in ConA, which results in a more open quaternary structure for the ConBr lectin [26]. We hypothesize that $\mathrm{ConBr}$ and ConA may bind to similar carbohydrate structures, exposed differently on cell surfaces, thereby triggering the distinct cell populations or inducing varied quantitative effects on the same cells.

Therefore, based on the experimental evidences available to date, we hypothesize that the different biological responses elicited by the well conserved family of Diocleinae lectins are mainly due to changes in three major physico-chemical parameters: binding specificity to complex carbohydrates, $\mathrm{pH}$-dependent oligomerization state (dimer-tetramer equilibrium) and the relative orientation of the carbodydrate-binding sites. The differences observed in these parameters among the lectins are likely to be the effect of specific amino acid replacements at key positions along their primary structures. The relative importance of each parameter in determining the biological activity of each lectin is still not understood.

\section{BIOLOGICAL ACTIVITIES OF DIOCL- EINAE LECTINS}

ConA has been widely used in a number of cell biology and lymphocyte physiology studies, most commonly as a prototypic cell mitogen. We have screened ConA-like lectins to evaluate whether small molecular differences between them could be reflected on their leukocyte stimulatory capacity.

The potential of nine glucose-mannose binding lectins from the subtribe Diocleinae to stimulate human lymphocyte proliferation in vitro was compared (Table 2). All lectins tested were mitogenic, but their potency varied. ConBr was the lectin with the highest lymphocyte proliferation index. Except for CABO and DguiL, all tested lectins have induced higher proliferation indexes than ConA, which showed only half of the stimulatory capacity of ConBr.

Further, we tested the ability of several Diocleinae lectins to induce cytokine production by human peripheral blood mononuclear cells (PBMC). Supernatants of PBMC cultures $48 \mathrm{~h}$ after in vitro stimulation were assessed by measuring GM-CSF, IL-4, IFN- $\gamma$, IL-10 and TNF- $\alpha$. GMCSF, a pro-inflammatory cytokine, and IL-4, a well known Th2 cytokine, were not detected in significant amounts in the supernatants of PBMC

Table 2. Comparative in vitro Immunological Activity of Lectins Obtained from Subtribe Diocleinae (Leguminosae, Phaseoleae)

\begin{tabular}{|c|c|c|c|c|c|c|c|c|c|c|}
\hline Induction of & ConA & ConBr & САBO & DGL & DVioL & DRL & DVirL & DGuiL & CFL & Ref \\
\hline Human PBMC activation ${ }^{1}$ & $50 \% *$ & $100 \%$ & $20 \%$ & $80 \%$ & $70 \%$ & $75 \%$ & $90 \%$ & $35 \%$ & $75 \%$ & 65 \\
\hline Histamine secretion & $100 \%$ & $100 \%$ & $10 \%$ & $10 \%$ & $50 \%$ & $100 \%$ & $100 \%$ & $50 \%$ & $10 \%$ & 66,67 \\
\hline Nitric oxide production $^{2}$ & $63 \%$ & $100 \%$ & nd & $62 \%$ & $2 \%$ & nd & $21 \%$ & $34 \%$ & nd & 69 \\
\hline
\end{tabular}

* All data shown in percentage refer to activity compared to values obtained with the lectin presenting the highest activity in the test. 1. Tests made on human PBMC; 2 . Tests in murine macrophages; $n d=$ not determined. 
cultures. On the other hand, all lectins tested induced high and variable amounts of TNF- $\alpha$ and IFN- $\gamma$, both strong macrophage-activating Th1type cytokines (Table 3). TNF- $\alpha$ participates in the intracellular parasite killing and in granulomatous inflammation [44-45], but on the other hand it is also associated with tissue destruction and might play a role in the immunopathology of some infectious diseases [44, 46]. The highest production levels of IFN- $\gamma$ were attained by DRL, followed by ConBr, while TNF- $\alpha$ was strongly induced by ConBr, followed by DvioL and DvirL. The absence of measurable IL-4 and presence of high levels of IFN- $\gamma$ in the supernatants of PBMC cultures suggest that these Diocleinae lectins might drive lymphocyte differentiation to the Th1 type.

The presence of IL-10 in the supernatants of human PBMC cultures stimulated by the Diocleinae lectins studied further indicates that these lectins are potent macrophage stimulators. IL-10 is a down-regulating cytokine that might help in driving lymphocyte responses towards the Th2 type [47-48]. The levels of IL-10 induced by lectin stimulation also vary; the higher amounts were present in the supernatants of cultures stimulated with ConA, ConBr and DGuiL.

To further evaluate the stimulatory capacity of these glucose-mannose binding lectins, we have measured the amounts of nitric oxide (NO) produced by $\mathrm{BALB} / \mathrm{c}$ peritoneal cells in culture under lectin stimulation. NO production often reflects macrophage stimulation. Our experiments show that ConA, ConBr and DGL attain high levels of nitric oxide induction in vitro (Table 2 ). $\mathrm{NO}$ is involved in several physiologic functions in the immune system of experimental animals; it shows cytostatic or cytotoxic action on various pathogens and on tumor cells [49], participates in acute inflammation models [50-52], and was shown to be involved in immune suppression and apoptosis induction under some circumstances [49, 53-56]. The observed stimulation of macrophages, as indicated by the production of TNF- $\alpha$, IL-10 and NO may be a direct effect of lectins on macrophages, or mediated by products liberated by activated lymphocytes. In any case, such stimulation may be important for the host in case of lectin administration.

Several lectins have been shown to present stimulatory effects in vivo [57]. To characterize the stimulatory capacity of ConBr, DGL and DVL in vivo, we have injected them in the footpad of $\mathrm{BALB} / \mathrm{c}$ mice. All lectins were able to induce a significant increase in lymph node cell numbers 15 hours after administration, the highest values being found in ConBr stimulated lymph nodes (Table 4). Cell number augmentation was accompanied by a remarkable enlargement of the lymph nodes,

Table 3. Cytokine Synthesis Induction by Lectins Obtained from Subtribe Diocleinae (Leguminosae, Phaseoleae)

\begin{tabular}{|c|c|c|c|c|c|c|c|}
\hline Synthesis of & ConA & ConBr & DGL & DVioL & DRL & DVirL & DGuiL \\
\hline \hline IL4 & $0.2[0.023 .0]$ & $0.5[0.310 .0]$ & $6.3[0.0-20.7]$ & $0.0[0.00 .6]$ & $4.2[3.258 .5]$ & $0.2[0.021 .0]$ & $3.5[0.320 .7]$ \\
\hline IL10 & $7.0[0.022 .0]$ & $1.6[0.875 .0]$ & $1.0[0.0-34.0]$ & $1.1[0.581 .0]$ & $\begin{array}{c}215.0[1.0 \\
329.0]\end{array}$ & $6.8[0.081 .0]$ & $\begin{array}{c}11.8[0.2 \\
124.0]\end{array}$ \\
\hline TNF $\alpha$ & $\begin{array}{c}311.5[193.0 \\
1074.0]\end{array}$ & $\begin{array}{c}1496.0[752.0 \\
1910.0]\end{array}$ & $\begin{array}{c}55.0[0.0- \\
623.0]\end{array}$ & $\begin{array}{c}668.0[58.0 \\
1060.0]\end{array}$ & $\begin{array}{c}277.5[0.0 \\
997.0]\end{array}$ & $\begin{array}{c}530.5[201.0 \\
1367.0]\end{array}$ & $\begin{array}{c}115.0[0.0 \\
1140.0\end{array}$ \\
\hline GMCSF & $0.6[0.31 .6]$ & $4.0[4.04 .5]$ & $0.5[0.0-36.6]$ & $1.5[0.52 .0]$ & $8.2[5.322 .0]$ & $\begin{array}{c}0.5[0.01 .7] \\
2.5[1.85 .2]\end{array}$ \\
\hline IFN $\gamma$ & $\begin{array}{c}1427.0[1357.0 \\
1636.0]\end{array}$ & $\begin{array}{c}1613.0[1341.0 \\
1831.0]\end{array}$ & $\begin{array}{c}986.0[299.0- \\
1226.0]\end{array}$ & $\begin{array}{c}1443.0[1342.0 \\
1529.0]\end{array}$ & $\begin{array}{c}1364.0[940.0 \\
1466.0]\end{array}$ & $\begin{array}{c}1408.0[1206.0 \\
1543.0]\end{array}$ & $\begin{array}{c}1504.0 \\
{[1364.0} \\
1635.0]\end{array}$ \\
\hline
\end{tabular}

* All data shown refer to activity obtained with human PBMC stimulation (median [min-max], values in pg/ml); nd= not determined. 
Table 4. Comparative in vivo immunological activity of Lectins obtained from subtribe Diocleinae (Leguminosae, Phaseoleae)

\begin{tabular}{|c|c|c|c|c|c|}
\hline Activity & ConA & $\mathrm{ConBr}$ & DGL & DVL & Ref \\
\hline Induction of IFN- $\gamma$ synthesis by murine lymphocytes & nd & yes & nd & nd & 60 \\
\hline Lymphocyte number increase in mouse lymph node & nd & $100 \% *$ & $71 \%$ & $67 \%$ & UD \\
\hline Lymphocyte activation in mouse lymph node & yes & yes & yes & yes & UD \\
\hline Cell death (apoptosis) in mouse lymph node & nd & yes & yes & yes & UD \\
\hline Cell death (necrosis) in mouse lymph node & no & no & yes & yes & UD \\
\hline Cell migration induction in mouse peritoneal cavity & $40 \%$ & $100 \%$ & $100 \%$ & nd & 32,61 \\
\hline Induction of mouse footpad edema. & $20 \%$ & $100 \%$ & $100 \%$ & nd & 61 \\
\hline
\end{tabular}

*All data shown in percentage refer to activity compared to values obtained with the lectin presenting the highest activity in the test. nd= not determined. UD $=$ Unpublished data.

expansion of lymph node paracortical areas and presence of numerous lymphoblasts, which strongly suggest that these lectins are potent $\mathrm{T}$ cell stimulators. Black and co-workers [58] have previously reported that the subcutaneous administration of ConA in the footpad of BALB/c mice leads to an increase of popliteal lymph node cell numbers concomitant to the up-regulation of IL-2R expression in lymphocytes. Bento and coworkers [33] have also shown popliteal lymph node cell number increase following s.c. administration of $\mathrm{ConBr}$ in $\mathrm{BALB} / \mathrm{c}$ mice footpads.

Strong NO production can also be induced in vivo in BALB/c mice upon lectin intraperitoneal administration, and was shown to be maintained for at least $48 \mathrm{~h}$ after lectin injection. The i.p. administration of $\mathrm{ConBr}$ also induced IFN- $\gamma$ production in $\mathrm{BALB} / \mathrm{c}$ mice [59]. These data indicate that the Diocleinae lectins may be potent lymphocyte and macrophage stimulators not only in vitro, but also in vivo.

Apoptotic cells are observed in lymph nodes draining paws injected with lectins (Table 4). Cell number increases in lymph nodes after $\mathrm{ConBr}$ or ConA subcutaneous administration, and there is a further increase when the animals are systemically treated with aminoguanidine, a nitric oxide blocking agent, suggesting that NO may be implicated in lectin-induced apoptosis.

Rodrigues and co-workers [32] have reported mononuclear and PMN leukocyte increases $24 \mathrm{~h}$ after intraperitoneal administration of $\mathrm{ConBr}$, DGL and ConA, reflecting cell recruitment to the site of injection (Table 4). An expressive edematous inflammatory reaction can be observed following the subcutaneous injection of $\mathrm{ConBr}$, ConA and DGL in BALB/c mice footpads [33]. The inflammatory capacity of the lectins might be linked to a long clearance period [60]. DGL induced inflammation presents some aspects in common with the Arthus reaction, produced by immunoglobulin deposition, despite proceeding apparently without participation of the complement system [61].

Fibrinoid necrosis is also characteristic of hypersensitivity reactions caused by immune complexes deposition [62]. Interestingly, DVLstimulated lymph nodes have often shown fibrinoid necrosis associated to the lymph node high endothelium venules, a feature also seen in some DGL-stimulated lymph nodes but never observed in ConBr-stimulated ones (Table 4). 


\section{BIOTECHNOLOGICAL APPLICATIONS}

Many plant lectins with different carbohydratebinding properties have toxic or inhibitory properties against insect pests when present both in the artificial diet and, in a few limited examples, in transgenic plants. The use of genetically engineered crops expressing lectin genes has therefore a great biotechnological potential in agriculture. Several studies have been carried out involving the screening of purified lectins against insect pests in an attempt to identify insecticidal proteins and hence isolate the genes encoding them for subsequent plant transformation [63].

We have evaluated the effect of nine Diocleinae lectins (Table 5) on the growth and development of third instar nymphs of Nilaparvata lugens, a monophagous pest of rice that has been described as the most destructive pest of the crop in Asia. All lectins were toxic when incorporated into artificial diets at $0.1 \%(\mathrm{~m} / \mathrm{v})$. Of the proteins tested, $\mathrm{ConBr}$ and ConA were the most effective producing the highest rates of corrected mortality $(64.6 \%$ for ConBr and $58.7 \%$ for ConA) and the highest reduction in the mean developmental time. Lectins mode of action is unknown, but may involve binding to glycoproteins present on the midgut epithelial cells resulting in a disruption of cellular function [64].

ConBr, the most toxic lectin to $N$. lugens, was further tested against the aphid Aulacortum solani. When incorporated into artificial diets at different levels $(0.025,0.05,0.1$ and $0.2 \%, \mathrm{~m} / \mathrm{v})$, ConBr had no deleterious effect on the growth and development of the nymphs. Indeed, the lectin produced a probiotic effect by which a stimulation in nymph production by the adults fed with the lectin diet was observed. Such findings illustrate the necessity of exercising caution in planning the environmental use of lectins, especially when considering their biotechnological applications in crop protection by the use of genetically engineered crops expressing lectin genes.

Lectins have been tested as drugs or as agents for drug targeting [65-67], as adjuvants in tumor treatment [68-70] and in diagnosis [71]. Orally administered lectins can stimulate the immune system, as shown in humans [72].

Another area where lectins have been widely used is cytochemistry or histochemistry. Lectin binding patterns has been shown to contribute in the histological identification of tumors [73-75]. ConA-like lectins tested in epithelial tumors exhibited similar staining patterns [76].

The use of lectins in the domain of microbiology and parasitology is extensive [7788]. Most applications deal with identification of the agent structures, and occasionally with protective effect against infection [59].

\section{CLOSING REMARKS AND FUTURE PERSPECTIVES.}

The data reviewed here make clear that many ConA-like lectins can diverge considerably in their physiological properties, despite minor differences in their structure. ConA-like lectins differed in their stimulatory capacity in several evaluations of immune function, often proving to be more potent stimulators then ConA. Such demonstration increases the available choices of stimulants for in vitro and in vivo tests of immunity; depending on the test to be used, a more appropriate lectin can

Table 5. Other Effects of Lectins Obtained from Subtribe Diocleinae (Leguminosae, Phaseoleae)

\begin{tabular}{|c|c|c|c|c|c|c|c|c|c|c|c|}
\hline Activity & ConA & ConBr & Con M & CABO & DGL & DVL & DRL & DVirL & DGuiL & CFL & Ref \\
\hline Insecticidal activity** & $100 \%$ & $100 \%$ & nd & $100 \%$ & $50 \%$ & $50 \%$ & $50 \%$ & $50 \%$ & $50 \%$ & $30 \%$ & 89 \\
\hline Probiotic effect $* * *$ & yes & $\mathrm{Nd}$ & nd & nd & nd & nd & nd & nd & nd & yes & 89 \\
\hline
\end{tabular}

* All data shown in percentage refer to activity compared to values obtained with the lectin presenting the highest activity in the test. nd= not determined. UD $=$ Unpublished data. **Activity determined on nymphs of Nilaparvata lugens. *** Effect determined on nymphs of Aulacorthum solani. 
be selected. It is worth reemphasizing that the diversity of potency was shown in very similar lectins, and that several other possibilities for lectins with specificities for other sugars remain unexplored.

The use of lectins as insecticides in agriculture is promising but must be evaluated with great care. In this area, the approach would be to transform plants with lectin genes, so that pests would ingest lectins that would impair their growth, or even lead to their death. The observation, however, that the same lectins can exhibit insecticidal actions against one pest and have a probiotic effect to another agent indicates that the use of geneticallyengineered lectin-producing plants requires rigorous scrutiny.

An extensive evaluaton of ConA-like lectins in other applications where lectins have proven to be useful has not been performed. In all approaches where the use of lectins has been shown, employing lectins with similar amino acid sequences may help in the identification of subtle differences. Attention to these effects may lead to the discovery of new tools.

The diverse actions of very structurally similar lectins illustrates how small changes in spatial conformation may have disproportionate effects on function. Different forms serving a gamut of functions - as for Proteus, so for lectins.

\section{ACKNOWLEDGMENT}

This work received support from PADCT. BSC, TBG and MB-N are Investigators of the Conselho Nacional de Desenvolvimento Científico e Tecnológico (CNPq)/Brazil.

\section{REFERENCES}

[1] Van Damme, E.J.M.; Peumans, W.J.; Barre, A. and Rougé, P. (1998) Crit. Rev. Plant Sci., 17, 575-692.

[2] Gabius, H-J. and Gabius, S. (eds.) (1997) in Glycoscience. Status and perspectives. Chapman and Hall, Weinheim.
[3] Chrispeels, M.J. and Raikhel, N.V. (1991) The Plant Cell, 3, 1-9.

[4] Peumans, W.J. and Van Damme, E.J.M. (1995) Plant Physiol., 109, 347-352.

[5] Peumans, W.J. and Van Damme, E.J.M. (1995) Histochem. J., 27, 253-71

[6] Hirsh (1999) Curr. Opin. Plant Biol., 2, 320-326.

[7] Rini, J.M. (1995) Annu. Rev. Biophys. Biomol. Struct., 24, 551-577.

[8] Summer, J.B. and Howell, S.F. (1936) American Journal of Bacteriology, 32, 227-237.

[9] Cunningham, B.A.; Wang, J.L.; Waxdal, M.J. and Edelman, G.M. (1975) J. Biol. Chem., 250, 15031512.

[10] Wang, J.L.; Cunningham, B.A.; Waxdal, M.J. and Edelman, G.M. (1975) J. Biol. Chem., 250, 14901502.

[11] Hardman, K.D. and Ainsworth, C.F. (1972) Biochemistry, 11, 1120-1128.

[12] Becker, J.W.; Reeke, G.N.; Wang, J.L.; Cunningham, B.A. and Edelman, G.M. (1975) J. Biol. Chem., 250, 1513-1524.

[13] Moreira, R.A. and Cavada, B.S. (1984) Biologia Plantarum (Praha), 26, 113-120.

[14] Moreira, R.A.; Barros, A.C.H.; Stewart, J.C. and Pusztai, A. (1983) Planta, 158, 63-69.

[15] Oliveira, J.T.A.; Cavada, B.S. and Moreira, R.A. (1991) Rev. Bras. Bot., 14, 63-68.

[16] Vasconcelos, I.M.; Cavada, B.S.; Moreira, R.A. and Oliveira, J.T.A. (1991) Journal of Food Biochemistry, 15, 137-154.

[17] Cavada, B.S.; Grangeiro, T.B.; Ramos, M.V.; Cordeiro, E.F.; Oliveira, J.T.A. and Moreira, R.A. (1996) Rev. Bras. Fisiol. Vegetal, 8, 31-36.

[18] Cavada, B.S.; Ramos, M.V.; Cordeiro, E.F.; Grangeiro, T.B.; Oliveira, J.T.A.; Carvalho, A.F.F.U. and Moreira, R.A. (1996) Rev. Bras. Fisiol. Vegetal, 8, 37-42.

[19] Cavada, B.S.; Moreira-Silva, L.I.M.; Grangeiro, T.B.; Santos, C.F.; Pinto, V.P.T.; Barral-Netto, M.; RoqueBarreira, M.C.; Gomes, J.C.; Martins, J.L.; Oliveira, J.T.A. and Moreira, R.A. (1996) Purification and biological properties of a lectin from Canavalia bonariensis Lind. seeds. (Van Driessche, E.; Fisher, 
J.; Beeckmans, S. and Bog-Hansen, T.C.; eds.), pp. 74-80, Textop, Denmark.

[20] Moreira, R.A.; Cordeiro, E.F.; Grangeiro, T.B.; Martins, J.L.; Ramos, M.V.; Oliveira, J.T.A. and Cavada, B.S. (1996) Rev. Bras. Fisiol. Vegetal 8, 2329.

[21] Maxwell, R.H. (1969) in The genus Dioclea (Fabaceae) in the new world. pp. 1-431, Southern Illinois University.

[22] Derewenda, Z.; Yariv, J.; Heliiwell, J.R.; Kalb (Gilboa), A.J.; Dodson, E.J.; Papiz, M.W.; Wan, T. and Campbell, J. (1989) EMBO J., 8, 2189-2193.

[23] Vijayan, M. and Chandra, N. (1999) Curr. Opin. Structural Biol., 9, 707-714.

[24] Cavada, B.S.; Moreira, R.A.; Oliveira, J.T.A. and Grangeiro, T.B. (1993). Rev. Bras. Fisiol. Vegetal, 5, 193-201.

[25] Moreira, R.d.A.; Ainouz, I.L.; De Oliveira, J.T. and Cavada, B.S. (1991) Mem. Inst. Oswaldo Cruz, 86, 211-8.

[26] Sanz-Aparicio, J.; Hermoso, J.; Granjeiro, T.B.; Calvete, J.J. and Cavada, B.S. (1997) FEBS Lett., 405, 114-118.

[27] Rozwarski, D.A.; Swami, B.M.; Brewer, C.F. \& Sacchettini, J.C. (1998) J. Biol. Chem., 273, 3281832825 .

[28] Wah, D.A.; Cavada, B.S.; Ramos, M.V.; Grangeiro, T.B.; Sampaio, A.H.; Calvete, J.J. and Romero, A. (2000) J. Mol. Biol. (submitted)

[29] Lee, H.C.; Goroncy, A.K.; Peisach, J.; Cavada, B.S.; Grangeiro, T.B.; Ramos, M.V.; Sampaio, A.H.; Dam, T.K. and Brewer, C.F. (2000) Biochemistry, 39, 23402346.

[30] Gomes, J.C.; Rossi, R.R.; Cavada, B.S.; Moreira, R.A.; and Oliveira, J.T.A. (1994) Agents Actions, 41, 132-135.

[31] Barral-Netto, M.; Santos, S.B.; Barral, A.; Moreira, L.I.M.; Santos, C.F.; Moreira, R.A.; Oliveira, J.T.A.; and Cavada, B.S. (1992) Immunol. Invest., 21, 297303.

[32] Rodrigues, D.; Cavada, B.S.; Oliveira, J.T.A.; Moreira, R.A. and Russo, M. (1992) Braz. J. Med. Biol. Res., 25, 823-6.

[33] Bento, C.A.; Cavada, B.S.; Oliveira, J.T.; Moreira, R.A. and Barja-Fidalgo, C. (1993) Agents Actions, 38, 48-54.
[34] Dam, T.K.; Cavada, B.S.; Grangeiro, T.B.; Santos, C.F.; Sousa, F.A.M.; Oscarson, S. and Brewer, C.F. (1998) J. Biol. Chem., 273, 12082-12088.

[35] Dam, T.K.; Cavada, B.S.; Grangeiro, T.B.; Santos, C.F.; Ceccatto, V.M.; Sousa, F.A.M.; Oscarson, S. and Brewer, C.F. (2000) J. Biol. Chem., 275, 1611916126

[36] Ramos, M.V.; Moreira, R.d.A.; Oliveira, J.T.; Cavada, B.S. and Rouge, P. (1996) Mem. Inst. Oswaldo Cruz, 91, 761-6.

[37] Ramos, M.V.; Moreira, R.A.; Cavada, B.S.; Oliveira, J.T.A. and Rougé, P. (1996) Rev. Bras. Fisiol. Vegetal, 91, 761-766.

[38] Ayouba, A.; Roques, D.; Cavada, B.S.; Oliveira, J.T.A.; Moreira, R.A. and Rougé, P. (1993) The carbohydrate-specificity of three lectins from the tribe Diocleae: Canavalia brasiliensis, Cratylia floribunda and Dioclea grandiflora. (Basu, J.; Kundu, M. and Chakrabarti, P.; eds.), pp. 51-57, Wiley Eastern, New Delhi, India.

[39] Naismith, J.H. and Field, R.A. (1996) J. Biol. Chem., 271, 972-976.

[40] Cavada, B.S.; Nogueira, N.A.P.; Farias, C.M.S.A.; Grangeiro, T.B.; Ramos, M.V.; Thole, H.H.; Raida, M.; Rougé, P. and Calvete, J.J. (1999) Protein and Peptide Letters, 6, 27-34

[41] Calvete, J.J.; Thole, H.H.; Raida, M.; Urbanke, C.; Romero, A.; Grangeiro, T.B.; Ramos, M.V.; Rocha, I.M.A.; Guimaraes, F.N. and Cavada, B.S. (1999) Biochimica et Biophisica Acta, 1430, 367-375.

[42] Grangeiro, T.B.; Schriefer, A.; Calvete, J.J.; Raida, M.; Urbanke, C.; Barral-Netto, M. and Cavada, B.S. (1997) Eur. J. Biochem., 248, 43-8.

[43] Licastro, F.; Davis, L.J. and Morini, M.C. (1993) Int. J. Biochem., 25, 845-852.

[44] Cavaillon, J.M. (1994) Biomed Pharmacother, 48, 445-53.

[45] Grau, G.E.; Lambert, P.H.; Vassalli, P. and Piguet, P.F. (1989) Schweiz Med Wochenschr, 119, 1756-61.

[46] Playfair, J.H. and Taverne, J. (1987) Ciba Found Symp, 131, 192-205.

[47] Romagnani, S. (1991) Int. J. Clin. Lab. Res., 21, 1528 .

[48] O'Garra, A. and Murphy, K. (1994) Curr. Opin. Immunol., 6, 458-66. 
[49] Marletta, M.A.; Tayeh, M.A. and Hevel, J.M. (1990) Biofactors, 2, 219-25.

[50] Moncada, S. and Higgs, A. (1993) N. Engl. J. Med., 329, 2002-12.

[51] Cattell, V. and Jansen, A. (1995) Histochem. J., 27, 777-84.

[52] Nussler, A.K. and Billiar, T.R. (1993) J. Leukoc. Biol., 54, 171-8.

[53] Moilanen, E. and Vapaatalo, H. (1995) Ann. Med., 27, 359-67.

[54] Albina, J.E. and Henry, W.L.; Jr. (1991) J. Surg. Res., 50, 403-9.

[55] Delaney, C.A.; Green, M.H.; Lowe, J.E. and Green, I.C. (1993) FEBS Lett., 333, 291-5.

[56] Fecho, K.; Maslonek, K.A.; Dykstra, L.A. and Lysle, D.T. (1995) J. Pharmacol. Exp. Ther., 272, 477-83.

[57] Lis, H. and Sharon, N. (1986) Annu. Rev. Biochem., 55, 35-67.

[58] Black, C.D.; Kroczek, R.A.; Barbet, J.; Weinstein, J.N. and Shevach, E.M. (1988) Cell Immunol., 111, 420-32.

[59] Barral-Netto, M.; Von Sohsten, R.L.; Teixeira, M.; dos Santos, W.L.; Pompeu, M.L.; Moreira, R.A.; Oliveira, J.T.; Cavada, B.S.; Falcoff, E. and Barral, A. (1996) Acta Trop., 60, 237-50.

[60] Mitchell, G.F. and Clarke, A.E. (1979) Int. Arch. Allergy Appl. Immunol., 58, 391-401.

[61] Lima, M.S.; Albuquerque, D.A.; Ibanez, O.M. and Sant'anna, O. (1993) Mem. Inst. Oswaldo Cruz, 88, 599-603.

[62] Johnson, K.J.; Chensue, S.W.; Kunkel, S.L. and Ward, P.A. (1995) in Essential Pathology (E.; R. and Farber, J.L.; Eds.). pp. 65-93. J.B. Lippincott Company, Philadelphia.

[63] Gatehouse, A.M.R.; Powell, K.S.; Peumans, W.J.; Van Damme, E.J.M. and Gatehouse, J.A. (1995) in Lectins: Biomedical Perspectives (Pusztai, A. and Bardocz, S.; Eds.). pp. 35-57. Taylor \& Francis, London.

[64] Harper, S.M.; Creenshaw, R.W.; Mullins, M.A. and Privalle, L.S. (1995) J. Economic Entomol., 88, 11971202.
[65] Negre, E.; Chance, M.L.; Hanboula, S.Y.; Monsigny, M.; Roche, A.C.; Mayer, R.M. and Hommel, M. (1992) Antimicrob. Agents Chemother., 36, 2228-32.

[66] Balzarini, J.; Schols, D.; Neyts, J.; Van Damme, E.; Peumans, W. and De Clercq, E. (1991) Antimicrob. Agents Chemother., 35, 410-6.

[67] Lord, J.M.; Roberts, L.M. and Robertus, J.D. (1994) FASEB J., 8, 201-208.

[68] Bocci, V. (1993) J. Biol. Regul. Homeost. Agents, 7, 1-6.

[69] Grossbard, M.L.; Multani, P.S.; Freedman, A.S.; O'Day, S.; Gribben, J.G.; Rhuda, C.; Neuberg, D. and Nadler, L.M. (1999) Clin. Cancer Res., 5, 2392-8.

[70] Stein, G.M. and Berg, P.A. (1999) Eur. J. Med. Res., $4,169-77$.

[71] Nagata, A.; Miura, M. and Komoda, T. (1991) Tumour Biol., 12, 35-44.

[72] Luther, P.; Reutgen, H.; Sehrt, I.; Renner, H.; Noack, K.; Schubert, K.-H. and Werchan, D. (1990) in Immunotherapeutic prospects of infectious diseases (Masihi, K.N. and Lange, W.; Eds.). pp. 227-231. Springer-Verlag, Berlin.

[73] Roth, J.; Saremaslani, P.; Warhol, M.J. and Heitz, P.U. (1992) Lab. Invest., 67, 263-269.

[74] Roth, J.; Zuber, C.; Komminoth, P.; Sata, T.; Li, W.P. and Heitz, P.U. (1996) Histochem. Cell Biol., 106, 131-48.

[75] Mitchell, B.S. and Schumacher, U. (1999) Histol. Histopathol., 14, 217-26.

[76] Queiroz, C.M.P. (1996) Caracterização de subpopulação de células neoplasicas malignas em efusões serosas: utilidade da imuno-citoquimica. pp. 129. Universidade Federal da Bahia, Salvador.

[77] Gattegno, L.; Ramdani, A.; Jouault, T.; Saffar, L. and Gluckman, J.C. (1992) AIDS Res. Hum. Retroviruses, 8, 27-37.

[78] Almeida, M.C.; Cuba, C.A.; de Sa, C.M.; Pharoah, M.M.; Howard, K.M. and Miles, M.A. (1993) Trans. R. Soc. Trop. Med. Hyg., 87, 325-9.

[79] Llovo, J.; Lopez, A.; Fabregas, J. and Munoz, A. (1993) J. Infect. Dis., 167, 1477-80.

[80] Corbel, M.J. and Abraham, A.M. (1992) FEMS Microbiol. Lett., 69, 245-8. 
[81] De Stefano, J.A.; Trinkle, L.S.; Walzer, P.D. and Cushion, M.T. (1992) J. Parasitol., 78, 271-80.

[82] Jarlov, J.O.; Hansen, J.E.; Rosdahl, V.T. and Espersen, F. (1992) J. Med. Microbiol., 37, 195-200.

[83] Kumar, S. and Pritchard, D.I. (1992) Parasite Immunology, 14, 233-237.

[84] Ravdin, J.I. and Murphy, C.F. (1992) J. Protozool., 39, 319-23.

[85] Athamna, A.; Ofek, I.; Keisari, Y.; Markowitz, S.; Dutton, G.G. and Sharon, N. (1991) Infect. Immun., 59, 1673-82.
[86] Hill, D.E.; Fetterer, R.H. and Urban, J.F.; Jr. (1991) Exp. Parasitol., 73, 376-83.

[87] Schottelius, J. (1989) Zool. Anz., 223, 198-210.

[88] Ready, P.D. and Smith, D.F. (1988) Trans. R. Soc. Trop. Med. Hyg., 82, 418.

[89] Grangeiro, T.B. (1996). PhD Thesis. pp. Universidade Federal do Ceará, Fortaleza. 